\title{
Drivers of Brand Switching Behavior in Mobile Telecommunications
}

\author{
By Nicholas Grigoriou* \\ Aveek Majumdar" \\ Lars Lie
}

\begin{abstract}
Brand switching refers to migration of users from one brand to another. Switching is associated with negative consequences such as declining market share and poor profitability. As such, mobile telecommunications user switching has become a critical issue facing mobile service providers. Drawn from an online self-completion survey of mobile telecommunications users $(N=24,141)$ across four countries, this study examines previously unexplored antecedent factors determining brand switching behavior of mobile telecommunications users, and the relative importance of those factors. The research identifies the overall dimensions of switching behavior and then validates a theoretical model. The regression model suggests weak coefficient of determination (R2) between the dependent and independent variables. The study bridges the theoretical and practical knowledge gap in the literature by examining factors influencing consumers' switching behavior. Two economically developed and two emerging economies were selected in this study to examine potential differences in consumers' behavior towards mobile telecommunications services in both emerging and developed markets, and help us understand the potential reasons for these differences.
\end{abstract}

Keywords: branding, mobile telecommunications, switching behavior

\section{Introduction}

Over the past 20 years, the telecommunications industry has experienced significant growth spurred by the highly competitive mobile telecommunications revolution (Svendsen \& Prebensen, 2013). Mobile phone handsets have changed the way consumers use them. Beyond making and receiving calls and sending short messages (SMS), today mobile phone handsets are used for data download, internet access, listening to music, playing games, GPS navigation, and videoconferencing. Malhotra and Kubowicz Malhotra (2013) posit that mobile phones have evolved into multi-tasking devices where $70 \%$ of usage is voice and $30 \%$ is data. Mobile telecommunications service providers continue to invest capital to improve their infrastructure and the quality of their service provision. In doing so, many of these mobile telecommunications service providers partner with handset manufacturers to ensure service compatibility, thus enriching the customer experience.

The growth of the mobile telecommunications industry has resulted in greater choice of services and service providers for consumers. In some nations, such as Australia, Bahrain, Latvia, and Luxembourg, the mobile phone penetration rate exceeds $100 \%$ (Chuang, 2011) as measured by the number of

\footnotetext{
* Lecturer in Marketing, School of Business, Monash University Malaysia, Malaysia.

† Associate Director, Client Services, The Nielsen Company, Malaysia.

$\star$ Senior Manager, Client Services, The Nielsen Company, Malaysia.
} 
mobile phones in circulation, per head of the population. More than five billion mobile service subscriptions support the notion that approximately $80 \%$ of the world's population communicates on the go (Global Mobile Suppliers Association, 2012). As new consumers enter this market, mobile telecommunications service providers must retain their existing customers and grow their customer base to sustain their revenue and market share (Malhotra \& Kubowicz Malhotra, 2013). Doing so requires, inter alia, the provision of service quality (Zeithaml, Berry, \& Parasuraman 1996). As Lim, Widdows, and Park (2006) demonstrate, service quality in the mobile services industry affects customer satisfaction and loyalty through economic and emotional factors.

This study addresses a gap in our existing knowledge of what causes brand switching behavior in the fast growing mobile telecommunications industry. We provide practical guidance to managerial decision makers in the industry by identifying and modeling the variables that cause consumers to switch mobile telecommunications brands. Further, we expand our theoretical understanding of the causes brand switching behavior by demonstrating the interrelationships among the variables that cause switching behavior and provide suggested guidelines for further research in this area. In doing so, we attempt to address the research question: What factors affect consumers' switching behavior for mobile telecommunications providers?

Understanding the factors affecting brand switching in the mobile telecommunications industry has important managerial implications for customer retention (Edward \& Sahadev, 2011; Kouser, Qureshi, Shahzad, \& Hasan 2012; Ooko, Nzomoi, \& Numo, 2014). In turn, understanding brand switching behavior assists firms in understanding customer loyalty determinants (Adjei \& Denanyoh, 2014) and with the design, development, and implementation of customer loyalty programs (Lee, Lee, \& Feick, 2001), which is seen as a pre-requisite for customer lifetime value (Heskett, 2002).

The rest of this paper is organized as follows. First we provide a review of the relevant literature of brand switching. We then propose research hypotheses and a conceptual model for empirical validation. Section four addresses the research methodology employed in this study. In section five we present the analysis of the data and the findings of our study. The paper ends with the conclusion from our finds.

\section{Literature Review}

\section{Brand Loyalty}

Brand loyalty is a concept that has attracted considerable scholarly attention from marketing practitioners and academics (Worthington, RussellBennett, \& Härtel, 2010). Brand loyalty consists of a consumer's commitment to repurchase or otherwise continue using the brand and can be demonstrated by repeated buying of a branded product over another (Farhat \& Khan, 2011). In today's competitive environment where consumers have numerous choices 
of brands, building and sustaining brand loyalty is crucial for the survival of firms (Ramaseshan \& Stein, 2014). Academic interest in brand loyalty reveals that brand loyalty is a multidimensional construct. For instance, brand loyalty has been empirically examined from brand personality perspective (Roy, Khandeparkar, \& Motiani, 2016), consumer brand experiences (Iglesias, Singh, \& Batista-Foguet, 2011), brand communities (Kamboj \& Rahman, 2016), brand equity (Guzmán, 2012), and brand switching behavior (Al-Kwifi $\&$ Ahmed, 2015). Considering the numerous benefits accrued through brand loyalty, scholarly research has focused on how to increase and sustain brand loyalty (Ha, John, Janda, \& Muthaly, 2011). One such approach is through the dual strategy and the reduction of churning.

\section{Customer Retention and Churning}

A fundamental premise of marketing involves the acquisition and retention of customers, given the incremental cost difference between acquiring a new customer and retaining an existing one. Within the mobile telecommunications sector, the cost of acquiring new customers is prohibitive for many service providers compared to the cost of retaining current customer (Coussement, Benoit, \& Van den Poel, 2010). Fornell and Wernerfelt (1988) posit that acquiring a new customer costs the telecommunications service provider four to five times as much as keeping an existing customer satisfied, whilst Seo, Ranganathan, $\&$ Babad (2008) found that figure to be closer to 15 times. Further, as scholars have noted, customer retention may result in perceptual, motivational, and behavioral consequences that are beneficial to the service provider (Bansal \& Taylor, 1999; Burnham, Frels, \& Mahajan, 2003). Thus, market driven firms place particular emphasis in their marketing on retaining existing customers while seeking to acquire new ones (Gustafsson, Johnson, \& Roos, 2005). This paradigm gave rise to the practice of relationship marketing (Verhoef, 2003).

Despite the growing body of literature on customer retention (Ngai, 2005), "churn" or customer movement between competitors, remains on ongoing problem for service providers (Keaveney \& Parthasarathy, 2001). In light of this, Berry and Linoff (2004) posit that within the mobile telecommunications industry, two types of churn exist. Voluntary churn refers to customers who decide to sever their relationship with their service provider, whereas involuntary churn refers to a situation where the service provider terminates the relationship with a customer, often due to non-payment of invoices. Whilst both churn types in the mobile telephone industry are reportedly high, exact churn rates are difficult to discern (Seo et al., 2008).

Consumers' desire and ability to switch service providers is often a function of switching costs. Switching costs include economic (e.g. financial) and non-economic (e.g. search effort) costs (Burnham et al., 2003). Switching costs are barriers to switching and they act as factors that make it difficult and costly for consumers to change service providers (Jones, Mothersbaugh, \& Beatty, 2000). Scholars have found that customer satisfaction is also linked to the desire to switch mobile telecommunications service providers (Shin \& Kim, 2008), although not all consumers who switch providers do so from a 
lack of customer satisfaction. For instance, within the mobile telephone industry, customers are prone to switching providers if a competing firm provides lower prices (Madden, Savage, \& Coble-Neal, 1999) or other value added service (Kim \& Yoon, 2004).

Research has shown that regulatory policy, like mobile phone number portability between service providers, affects consumers' switching behavior. In nations where number portability exists, consumers can retain their mobile number while switching between providers.

To reduce "churn" rates in the mobile telephone industry, Lai, Griffin, and Babin (2009) recommend service providers focus on delivering service quality, customer satisfaction, and increasing in perceived value in the service provision. Table 1 summarizes the literature factors influencing churn rates among mobile telecommunications users. Most of the studies identified in Table 1, have examined churn from a single country perspective. Our study expands our knowledge of churn by comparing churn factors previously identified in the literature, from a four country perspective.

Our decision to examine brand switching behavior from a multi country perspective stems from repeated calls to move away from single country studies in marketing (Dawar \& Parker, 1994) in light of converging consumer tastes for consumer goods (Smith \& Mitry, 2007) in an era of globalization (Applbaum, 2000). Indeed, as Sin, Cheung, and Lee (1999) have posited, studies that investigate only one or two national cultures may have limited values compared to studies done in several cultures. Therefore, in line with Sekaran (1983), our study embodies several countries to give us a better and deeper understanding of consumer switching behavior.

Table 1. Factors Impacting Churn Rates in Mobile Telecommunications

\begin{tabular}{|l|l|}
\hline Factor & Source \\
\hline Attractive competitor pricing & $\begin{array}{l}\text { Gerpott, Rams, and Schindler (2001); Lee and } \\
\text { Cunningham (2001) }\end{array}$ \\
\hline Precision of billing & Lee and Cunningham (2001) \\
\hline $\begin{array}{l}\text { Switching costs/Switching } \\
\text { barriers }\end{array}$ & $\begin{array}{l}\text { Keaveney (1995); Kim and Yoon (2004); Shin and } \\
\text { Kim (2008); Vázquez-Carrasco and Foxall (2006) }\end{array}$ \\
\hline $\begin{array}{l}\text { Number of complaints (against } \\
\text { the provider) }\end{array}$ & Ahn, Han, and Lee (2006) \\
\hline Coverage area & Lee and Cunningham (2001) \\
\hline User demographics & $\begin{array}{l}\text { Ranganathan, Seo, \& Babad (2006); Rogers } \\
\text { (1995); Shin and Kim (2008) }\end{array}$ \\
\hline Call drop rate & Ahn et al. (2006) \\
\hline Number portability & $\begin{array}{l}\text { Kaur and Sambyal (2016); Nimako, Ntim, and } \\
\text { Mensah (2014) }\end{array}$ \\
\hline Perceived service quality & Shin and Kim (2008) \\
\hline $\begin{array}{l}\text { Quality of the information } \\
\text { exchange (between provider and } \\
\text { customer) }\end{array}$ & Gerpott et al. (2001) \\
\hline Network quality & Gerpott et al. (2001) \\
\hline $\begin{array}{l}\text { Quality of customer } \leftarrow \rightarrow \text { service } \\
\text { provider relationship }\end{array}$ & Hossain and Suchy (2013) \\
\hline
\end{tabular}


Table 1 illustrates the diverse antecedents affecting churn rates and by extension customer retention in the mobile telecommunications industry. From a marketing viewpoint, telecommunications firms attempt to influence their consumers' perceptions of switching, either by trying to entice new customers to the brand, retain existing customers, or both. Regrettably, as Burnham et al. (2003, p. 110) posit, "the existence of perceptions of switching costs has, by and large, been supported by anecdotes, logic, and simplistic measures that do not reflect the multidimensional nature of switching behavior discussed in the literature." To address Burnham, et al.'s (2003) concerns, this study examines the previously unexplored factors influencing consumers' decision to switch mobile telecommunications providers.

\section{Research Objectives and Hypotheses}

Switching intention is the propensity of a consumer to terminate their relationship with one supplier with the aim of using an alternative supplier of the same (or similar) service (Chuang, 2011; Ping Jnr, 1994). Studies on switching behavior suggest possible linkages between switching behavior as a dependent variable, and a range of predictor variables. Whilst many of the predictor variables are identified in Table 1 , several variables that potentially have the effect of determining switching behavior have yet to receive scholarly attention. This study aims to address this gap in our knowledge. Drawing upon prior research (Bansal \& Taylor, 1999; Gerrard \& Cunningham, 2004; Han, Back, \& Kim, 2011; Hossain \& Suchy, 2013; Kim, Park, \& Jeong, 2004), we develop several under-examined factors of customer brand switching behavior in mobile telecommunications. These include voice quality, billing experience, data download quality, and pricing plans. Importantly, we acknowledge that brand switching behavior may be influenced by a greater number of factors than what is examined in this study. To determine whether consumers of mobile telecommunications services intend to switch their provider, six independent variables previously unexplored in the literature were selected.

\section{Voice Communications Quality}

Despite the multiple applications and uses embedded in mobile phone handsets, the primary application, voice communications, dominates mobile telecommunications usage throughout the world (Lim et al., 2006). Thus, the provision of quality voice communications is important an important determinant of consumers likelihood to switch providers (Kim et al., 2004). In a service context, Zeithaml, Berry, \& Parasuraman (1996) define quality as the difference between consumer expectations of "what they want" and their perceptions of "what they get." In light of this we posit, 
H1: The better the perceived voice communications quality provided by the mobile telecommunications provider, the less likely consumers are to switch mobile telecommunications brands.

\section{Data Download Quality}

Whilst previous research on data download quality has addressed this value proposition (Chae, Kim, Kim, \& Ryu, 2002), its importance to switching behavior remains untested (Lim et al., 2006). As previously stated, consumers are increasingly using their mobile telephones for applications other than just making and received phone calls and text messages. Such applications include downloading music, checking emails, mobile banking, participating in social media, and accessing real time news content. Thus, we post,

H2: The better the perceived data download quality provided by the mobile telecommunications provider, the less likely consumers are to switch mobile telecommunications brands.

\section{Billing Experience}

The ways in which mobile telecommunications bills are prepared, and the usage fees are calculated, vary from provider to provider. However, most providers separate services such as web browsing from monthly rental fees, calls, and text messages (Roto, Geisler, Kaikkonen, Popescu, \& Vartiainen, 2006). Thus many of the mobile telephone charges are either fixed (such as a monthly rental) or variable (e.g. amount of data downloaded and uploaded, or duration of outgoing calls). Given the complexity of data usage based billing (Roto et al., 2006), especially for data downloading, it is often difficult for consumers to understand the charges on their mobile telecommunications bill. It is therefore the responsibility of mobile telephone provider to explain, in layman's terms, how the charges on the billing statement were calculated. We therefore posit,

H3: The better the perceived billing experience provided by the mobile telecommunications provider, the less likely consumers are to switch mobile telecommunications brands.

\section{Pricing Plans}

One of the ways in which mobile telecommunications service providers differentiate their offerings, and target separate segments of the market, is through their various pricing plans (Madden, Coble-Neal \& Dalzell, 2004). Pricing plans either center on the service usage (e.g. calls, text messaging, and data downloads) only, or handset and service usage which involves consumers paying off the price of the handset along with the monthly service fees together (i.e. by paying for the handset in monthly installments along with the services 
charges). Thus, the telephone firm offers different pricing structures, each specifying a fixed fee that must be paid up-front, a marginal usage price, and in addition use-of-service restrictions which consumers must pay. Customers then choose their preferred pricing structure and usage is subsequently billed according to this choice (Jensen, 2006). Therefore, we posit,

H4: The better the perceived pricing plans provided by the mobile telecommunications provider, the less likely consumers are to switch mobile telecommunications brands.

\section{Call Center Experience}

Marsico (1996) demonstrates that a service provider's relationship with the customer does not end at the completion of the transaction. Customer driven organizations establish call centers to provide after-hours service to consumers as a value added proposition either pre- or post-sale (Feinberg, Kim, Hokama, de Ruyter, \& Keen, 2000). They suggest that call centers form the new battleground for customer satisfaction, and allow firms to differentiate themselves from competitors. As such, we posit,

H5: The better the perceived call center experience provided by the mobile telecommunications provider, the less likely consumers are to switch mobile telecommunications brands.

\section{In-Store Experience}

Organizations use multi-channel integration (e.g. online and physical store) to increase customer satisfaction (Burke, 2002). Under an integrated multi-channel strategy, the retailer aims to provide a holistic customer engagement experience, so that the virtual/on-line experience mimics that of an in-store experience. As Verhoef et al. (2009) suggest, the two experiences are inter-related such that the perception of one customer experience influences the perception of the other. We therefore posit,

H6: The better in-store experience provided by the mobile telecommunications provider, the less likely consumers are to switch mobile telecommunications brands.

\section{Country Location of the Consumer}

In the past 15-20 years fixed line telecommunications has increasingly been complemented and also replaced by mobile telecommunications (ITU, 2002). Despite the trends towards increased mobile telecommunications usage, the penetration rates for mobile telecommunications differs between economically developed and emerging nations (Rouvinen, 2006). Indeed, the international diffusion of mobile telecommunications has been the subject of scholarly 
interest in various national contexts including India (Gupta and Jain, 2012), Vietnam (Hwang, Cho, \& Long, 2009), and China (Liu, Wu, \& Chu, 2009). Further, in emerging economies, research has revealed the adoption of mobile telecommunications services varies between rural and urban areas due to unique adoption behavior among consumers (Gupta and Jain, 2014, 2015). Further, in a 64 country study, Ahn and Lee (1999) found that high per capita GDP and fixed line penetration promote the diffusion of mobile telecommunications services. Similarly, in a ten country study within the European Union (Gruber, 2001) mobile telecommunications penetration was affected by the number of mobile service providers (operators), the level of penetration of fixed telecommunications services, and waiting times for connection. Finally, Madden, et al.'s (2004) 56 country study found high wealth, low user cost, and large user (customer) base promote the diffusion. This give rise to the idea that a country's level of economic development, influences consumers' perceptions of service provision quality (Carraher, Carraher, \& Mintu-Wimsatt, 2005).

Given the previous research on country differences on consumers' adoption of mobile telecommunications services, in this study we will use country location of the consumer of mobile telecommunications services as a moderator variable. Thus, we posit

H7a: The relationship between a mobile telecommunications provider's voice quality and a consumer's brand switching tendency is moderated by the country location of the consumer.

H7b: The relationship between a mobile telecommunications provider's data quality and a consumer's brand switching tendency is moderated by the country location of the consumer.

H7c: The relationship between a mobile telecommunications provider's billing service and a consumer's brand switching tendency is moderated by the country location of the consumer.

H7d: The relationship between a mobile telecommunications provider's pricing plans and a consumer's brand switching tendency is moderated by the country location of the consumer.

H7e: The relationship between a mobile telecommunications provider's call center service and a consumer's brand switching tendency is moderated by the country location of the consumer.

H7f: The relationship between a mobile telecommunications provider's instore service provision and a consumer's brand switching tendency is moderated by the country location of the consumer. 


\section{Proposed Theoretical Model for Empirical Validation}

From the identification and classification of the relevant variables, the following conceptual framework based on hypothetic-deductive reasoning for empirical testing is proposed.

Figure 1. Proposed Theoretical Model

\begin{tabular}{|c|c|c|}
\hline Voice Quality (H1) & \\
\hline Data Download Quality (H2) & & \\
\hline Billing Experience (H3) & & \\
\hline Pricing Plans (H4) & & \\
\hline Call Center Experience (H5) & & Consumers' Brand \\
Switching \\
Intentions
\end{tabular}

\section{Methodology}

\section{Overview}

To test the conceptual model in Figure 1, a positivist research paradigm using quantitative research design was used to examine the hypothesized relationships among the variables to test and validate constructed concepts about how the selected phenomena related to each other (Johnson \& Onwuegbuzie, 2004). Given the dual need to generate and confirm theories of switching behavior, a deductive approach was adopted to facilitate the management and analysis of the data arising from the field work.

\section{Data Collection}

Data was collected in a multi country study. For this study, the dataset consisted of 24,141 respondents from four countries. All respondents were of adult age and had previously purchased a mobile telecommunications plan with their preferred service provider. The sampling was conducted via an online survey using a consumer panel of a global panel company. The countries in this study were selected on the basis of their economic development (two developed economies, two emerging economies) for comparison purposes. The data were gathered via an online survey over a four month period in 2014. The data was weighted by the market size of the telecommunication brands. 
The number of telecommunications brands covered in each country varied between three and seven, as illustrated below:

China: 3 (China Mobile, China Unicom, China Telecom)

India: 7 (Airtel, Vodafone, Reliance Communication, Idea, BSNL, Aircel, Uninor)

Japan: 5 (NTT Docomo, KDDI Mobile, SoftBank Mobile, EMOBILE, Willcom)

USA: 6 (AT\&T, Verizon, Sprint, T-Mobile, Cellular One, US Cellular)

\section{The Sample}

The sample consists of adult users of mobile telecommunications services across the four countries. The sample size per country is illustrated in Table 2. Filter questions were included to ensure that respondents were using a postpaid account with their mobile telecommunications provider. A further filter question ensured that respondents had a personal account with their provided, and not one paid for by their employer, i.e. the mobile phone was used for personal use and the monthly account was paid by the responded. Respondents were asked to rate their experience with their mobile telecommunications provider on a range of dimensions.

Table 2. Distribution of Respondents per Country

\begin{tabular}{|l|c|}
\hline Country & $\mathbf{N}$ \\
\hline China & 6,016 \\
\hline India & 5,090 \\
\hline Japan & 4,008 \\
\hline US & 9,027 \\
\hline Total & $\mathbf{2 4 , 1 4 1}$ \\
\hline
\end{tabular}

\section{Variable Identification}

The dependent variable in this study is consumers' brand switching intention. A key component in any customer switching prevention strategy is customer satisfaction (Jones et al., 2000). The dependent variable was developed in response to the following survey question: If another service provider were to offer you a similar service, how likely are you to switch from your current service provider to the new provider? To measure the independent variable, a scale was adapted from the prior literature, most notably Heide and Weiss (1995). The wording of the original items was changed to reflect the present context.

The respondents were asked to answer on a five-point Likert scale $(5=$ extremely satisfied ... 1 = extremely unsatisfied) the following question: Based on your experience with (service provider) in the last three months, how you would rate their performance on 
1. Voice Quality.

2. Data Quality.

3. Billing Experience/Recharge experience.

4. Pricing Plans.

5. Call Center Experience.

6. In Store/Outlet experience.

In addition to the six independent variables, the county location of the telecommunications provider was used as a moderating variable to test the strength of the relationship between the dependent and independent variables. To examine the moderating effects of country location, the total sample was divided into the four focal countries from which data were collected. The countries and sample sizes per country are illustrated in Table 2.

\section{Questionnaire Design}

Survey research was used to collect numerical data to test our stated hypotheses. Specifically, our research instrument was designed to collect data related to the attitudes, practices and perceptions of mobile telecommunications consumers regarding brand switching behavior. To measure the constructs, procedures were derived from the extant literature. We used Chang and Chen's (2007) service sector loyalty scale and adapted it for mobile telecommunications services. The survey was issued to adults in the focal countries via an online survey. The survey included filter questions to preclude non-adults from participating in the survey, and to ensure the responded was currently using a paid mobile telecommunications plan.

\section{Data Analysis and Findings}

To examine the hypothesized relationships among the variables, we conducted a logistic regression analysis in line with the recommendations of Dayton (1992). Our empirical findings validate the hypotheses of this research, and a number of management implications can be derived.

All independent variables indicated that higher rated performance by a service provider will decrease the probability of brand switching (i.e. increase the likelihood of customer retention). Thus, consumers are less likely to switch brands when a service provider was rated higher than its competitors on their provision of mobile telecommunications services However, our logistic model coefficient does not interpret the size of the marginal effect. Therefore, we can only posit if the independent variables have a positive or a negative effect on the dependent variable.

We found that data quality, billing experience, voice quality, pricing plans, call center experience and in-store experience were found to have a positive effect on customer retention across the four countries, holding all other variables constant, as the p-value is lower than 0.05 at the $95 \%$ confidence interval. This means consumers were less likely to switch brands when the telecommunications 
service provider improved their provision of these services across the four countries. The managerial implication of this finding for telecommunications firms provides insights as to what specific aspects of the firms' value proposition is likely to drive, or result, in brand switching behavior. Accordingly, organizational resources should be focused towards improving these service dimensions.

\section{Parameter Estimates}

Table 3 summarizes the parameter estimates for the variables in the study. Variables with a positive estimate and significance value of less than 5\% suggest that such variables have a positive influence on customer retention while other variables are held. That is, the variables with positive scores make a positive contribution to customer retention.

Table 3. Parameter Estimates

\begin{tabular}{|c|c|c|c|c|c|c|c|c|c|}
\hline \multirow{2}{*}{\multicolumn{2}{|c|}{ req17t2b ${ }^{a}$}} & \multirow[t]{2}{*}{ B } & \multirow[t]{2}{*}{$\begin{array}{c}\text { Std. } \\
\text { Error }\end{array}$} & \multirow[t]{2}{*}{ Wald } & \multirow[t]{2}{*}{ df } & \multirow[t]{2}{*}{ Sig. } & \multirow[t]{2}{*}{$\operatorname{Exp}(B)$} & \multicolumn{2}{|c|}{$\begin{array}{c}95 \% \\
\text { Confidence } \\
\text { Interval for } \\
\operatorname{Exp}(\mathbf{B})\end{array}$} \\
\hline & & & & & & & & $\begin{array}{l}\text { Lower } \\
\text { Bound }\end{array}$ & $\begin{array}{l}\text { Upper } \\
\text { Bound }\end{array}$ \\
\hline \multirow[t]{11}{*}{1.00} & Intercept & -5.19378 & 0.290 & 319.929 & 1 & 0.000 & & & \\
\hline & Voice Quality & 0.14281 & 0.057 & 6.180 & 1 & 0.013 & 1.154 & 1.031 & 1.291 \\
\hline & Data Quality & 0.17393 & 0.057 & 9.450 & 1 & 0.002 & 1.190 & 1.065 & 1.330 \\
\hline & $\begin{array}{l}\text { Billing/Recharge } \\
\text { experience }\end{array}$ & 0.18657 & 0.057 & 10.675 & 1 & 0.001 & 1.205 & 1.078 & 1.348 \\
\hline & VAS experience & 0.25044 & 0.062 & 16.302 & 1 & 0.000 & 1.285 & 1.138 & 1.451 \\
\hline & $\begin{array}{l}\text { In-store/outlet } \\
\text { experience }\end{array}$ & 0.15166 & 0.058 & 6.854 & 1 & 0.009 & 1.164 & 1.039 & 1.304 \\
\hline & Rate plans/price & 0.25716 & 0.049 & 27.341 & 1 & 0.000 & 1.293 & 1.174 & 1.424 \\
\hline & Country $=1$, USA & -0.62986 & 0.108 & 34.194 & 1 & 0.000 & 0.533 & 0.431 & 0.658 \\
\hline & Country $=7$, China & -0.21427 & 0.091 & 5.524 & 1 & 0.019 & 0.807 & 0.675 & 0.965 \\
\hline & Country =8, Japan & -0.66083 & 0.117 & 31.752 & 1 & 0.000 & 0.516 & 0.410 & 0.650 \\
\hline & Country= 9, India & $0^{\mathrm{b}}$ & & & 0 & & & & \\
\hline
\end{tabular}

Table 4 summarizes the results of the maximum likelihood ratios. It suggests that voice quality is the least likely reason consumers across the four focal countries have to switch mobile telecommunications brands, whilst pricing plan ranks among the most important reason for brand switching in this industry. Given the frugal and price sensitive nature of consumers in two of the four countries in the study, namely China (Zheng, 1994) and India (Eckhardt \& Mahi, 2012), and the intense nature of competition in the other two, this result is not surprising. This result may also reflect the changing nature of the way mobile telecommunications is being used, that is, the mobile device is increasingly used for non-vocal communication and entertainment (Yun, 2012). 
Table 4. Likelihood Ratio Test

\begin{tabular}{|c|c|c|c|c|c|c|c|}
\hline \multirow[t]{2}{*}{ Effect } & \multicolumn{3}{|c|}{ Model Fitting Criteria } & \multicolumn{3}{|c|}{$\begin{array}{c}\text { Likelihood Ratio } \\
\text { Tests }\end{array}$} & \multirow{2}{*}{$\begin{array}{c}\text { Importance } \\
\text { ranking } \\
\text { based on } \\
\text { likelihood } \\
\text { ratio tests }\end{array}$} \\
\hline & $\begin{array}{c}\text { AIC of } \\
\text { Reduced } \\
\text { Model }\end{array}$ & $\begin{array}{c}\text { BIC of } \\
\text { Reduced } \\
\text { Model }\end{array}$ & 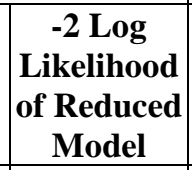 & $\begin{array}{c}\text { Chi- } \\
\text { Square }\end{array}$ & df & Sig. & \\
\hline Intercept & 3401.372 & 3477.585 & $3377.372^{\mathrm{a}}$ & 0.000 & 0 & & \\
\hline Voice Quality & 3405.534 & 3475.396 & 3383.534 & 6.162 & 1 & 0.013 & 9 \\
\hline Data Quality & 3408.822 & 3478.685 & 3386.822 & 9.451 & 1 & 0.002 & 6 \\
\hline Billing & 3410.049 & 3479.911 & 3388.049 & 10.677 & 1 & 0.001 & 5 \\
\hline VAS & 3415.773 & 3485.635 & 3393.773 & 16.401 & 1 & 0.000 & 4 \\
\hline In-Store Exper & 3406.200 & 3476.062 & 3384.200 & 6.828 & 1 & 0.009 & 7 \\
\hline Rate Plan/Price & 3426.880 & 3496.742 & 3404.880 & 27.508 & 1 & 0.000 & 2 \\
\hline Length of tenure & 3425.600 & 3495.462 & 3403.600 & 26.228 & 1 & 0.000 & 3 \\
\hline $\begin{array}{l}\text { Country of } \\
\text { Residence }\end{array}$ & 3441.617 & 3498.777 & 3423.617 & 46.246 & 3 & 0.000 & 1 \\
\hline Type of contract & 3406.116 & 3475.978 & 3384.116 & 6.744 & 1 & 0.009 & 8 \\
\hline
\end{tabular}

Notes: The chi-square statistic is the difference in $-2 \log$-likelihoods between the final model and a reduced model. The reduced model is formed by omitting an effect from the final model. The null hypothesis is that all parameters of that effect are 0 .

${ }^{a}$ : This reduced model is equivalent to the final model because omitting the effect does not increase the degrees of freedom.

In summary, previous brand switching studies in the services sector (De Ruyter, Wetzels, \& Bloemer, 1998; Gremler \& Brown 1996), mobile telecommunications consumers tend to be loyal to the present service provider unless they experience dissatisfaction with the services offered by that provider (Gustaffson et al., 2005; Lee \& Neale, 2012). Maintaining existing customers assist the service firm to maintain revenue streams. More importantly, as Reichheld \& Sasser (1990) noted, existing customers spend at an increasing rate and often purchase higher margin services.

The strength of country of residence as a moderator variable in our model is explained by the relative homogeneity of each country's culture, the size and openness of the home-country economy, and the cultural and institutional diversity of the environments in which the telecommunications provider operates (Noorderhaven \& Harzing, 2003). Table 5 reflects the moderating effects across the four countries. The coefficients under each country vary significantly, that is, the strengths of relationship between independent variables and the dependent variable is affected by country.

Table 5. Moderation Effects by Country

\begin{tabular}{|l|c|c|c|c|c|c|}
\hline Country & & & & & Wald & P-value \\
\hline USA & -1.07 & -1.12 & -0.36 & 2.56 & 48.9001 & 0.000 \\
\hline China & -0.13 & -0.28 & 0.74 & -0.33 & & \\
\hline Japan & 1.68 & 1.11 & -1.81 & -0.98 & & \\
\hline India & -0.48 & 0.29 & 1.43 & -1.25 & & \\
\hline
\end{tabular}




\section{Overall Model}

The model indicates relatively weak overall correlative relationships among the variables as indicated by the R-squared values in Table 6 . Three possible reasons may explain why low $\mathrm{R}$-squared values are acceptable in social science research. First, relatively low R-squared values are common in social sciences where human (consumer) behavior is being predicted. The relatively low values are not uncommon in the extant marketing literature (Reisinger, 1997). This is because human behavior is difficult to accurately predict. Second, despite the relatively low R-square value in our model, models with low factor loadings can still yield excellent goodness of fit (Chin, 1998). Finally, even though the purchase of mobile phone telecommunications plans tends to be an individual consumer in the United States, in collectivist countries such as China and India, these consumer choice decisions are influenced by groups (e.g. family, peers, and friends). These influential groups may also have a say as to whether the mobile telecommunications subscriber switches brands if they are dissatisfied with a service provider. The data analysis in this study only captures individual choice decisions, and not non-marketing related factors that influenced the decision.

Table 6. Model Classification

\begin{tabular}{|l|c|c|c|}
\hline \multirow{2}{*}{ Observed } & \multicolumn{3}{|c|}{ Predicted } \\
\cline { 2 - 4 } & $\mathbf{0 . 0 0}$ & $\mathbf{1 . 0 0}$ & Percent Correct \\
\hline $\mathbf{0 . 0 0}$ & 1963.9704 & 493.7884 & $79.9 \%$ \\
\hline $\mathbf{1 . 0 0}$ & 718.5516 & 1058.5636 & $59.6 \%$ \\
\hline Overall Percentage & $63.3 \%$ & $36.7 \%$ & $71.4 \%$ \\
\hline R-squared (Nagelkerke) & $27 \%$ & & \\
\hline$\%$ Correct Classification & $71 \%$ & & \\
\hline
\end{tabular}

At a national level, the four focal countries in this study provide useful managerial insights. For instance, whilst pricing rate plans were shown to have an effect on consumers' brand switching tendencies across all four countries, analysis on a per country basis reveal results which have managerial implications for how mobile telecommunications marketers design and communicate their value proposition. The USA and China were shown to have the highest price sensitive consumers, that is, consumers who were more likely to switch brands if they were offered a superior pricing rate plan form a competitor. Whilst Chinese consumers have historically demonstrated frugality in their discretionary consumption ( $\mathrm{Li}$, Jiang, An, Shen, \& Jin, 2009) which may explain their price sensitive nature, there is little evidence to suggest that frugality has historical or cultural roots in USA consumers' behavior. A similar argument can be made for India, whose consumers did not rank a mobile telecommunications provider's price rate plans as a significant reason for switching mobile telecommunications brands. Yet historically, Indian consumers have exhibited frugal consumption tendencies (Eckhardt \& Mahi, 2012). These results are even more pertinent in developing economies such as India and China, with a growing middle class of consumers whose personal income and expenditures on, inter alia, luxury goods are increasing (He, Zou, \& Jin, 2010). 


\section{Discussion}

To build relationships with customers, service providers need to understand how to retain existing customers and increase their loyalty to the service provider (Dawes \& Swailes, 1999; Harrison, 2000). Accordingly, a consumer's propensity to switch service provider is contingent on a number of factors, mainly centered on the perceived quality of service provision (Manrai \& Manrai, 2007). The results of this study offer some strategic implications for mobile telecommunications firms seeking to reduce customer switching. Whilst our results demonstrate that consumers are less likely to switch brands when the mobile telecommunications provider improved their provision of services, an insight from this study is to understand which specific service factors are sought by mobile telecommunications consumers when considering brand switching or level of satisfaction. Not surprisingly, each of the service provision dimensions identified in this study makes up the core of a mobile telecommunications providers value proposition.

Understanding consumers' brand switching tendencies is critical in determining strategies on retaining existing and acquiring new consumers, and increasing loyalty to the brand (Harrison, 2000). Managers of mobile telecommunications services must establish their own set of measures to gauge customer satisfaction (Athanassopoulos, 2000). In doing so, it is clear that many variables, some controllable, for example customer service provision (Gustafsson et al., 2005), others uncontrollable, for instance cultural differences (Money, 2004) that potentially affect consumers' brand switching behavior.

The managerial implications of this study center on the notion of understanding consumers' brand switching intentions and behaviors (see, for instance Martins, Hor-Meyll, and Ferreira, 2013). Understanding consumers' brand switching intentions and behaviors, whilst relevant in light of the findings of the present study, has adjunct practical implications for marketing managers and non-marketing managers. For instance, an organization's staff is at the forefront of the firm-consumer interface. Staff training must not only focus on providing sufficient service to customers (Santouridis \& Trivellas, 2010), but also providing the staff with the relevant training (Akroush, Abu-ElSamen, Al-Shibly, \& AlKhawaldeh, 2010) to detect dissatisfied customer who may defect to alternative mobile telecommunications brands. Such training implies an additional, and important, managerial implication: the notion that managers can transform existing customer service staff from a product centric to a customer centric focus (Duffy, 2000). Indeed, such a transformation should be a firm wide managerial imperative.

In an era of customer engagement, where market driven organizations are focused on understanding customer engagement behaviors (Van Doorn et al., 2010), a further managerial imperative resulting from this study, is to examine the relationship between customer engagement and brand switch behavior, that is, how preventing brand switching behavior may result in improved customer engagement in line with the findings of Hollebeek (2011). The results of such an examination may pave the way for market driven organizations developing an improved customer relationship management (CRM) system (Nguyen, Sherif, \& Newby, 2017). 
The finding of USA consumers' tendencies to switch mobile telecommunications brands on the basis of superior offers from competing brands has important managerial implications for how marketers segment and targeting consumers in the USA. The mobile telecommunications product's value proposition and ultimate success in the market depends on it.

\section{Theoretical Implications}

The findings of our study have theoretical implications within the marketing and consumer behavior domain. For instance, we address the important role of the service quality construct in affecting brand switching behavior. Service quality provision, in turn, has been theoretically linked to service loyalty (De Ruyter et al., 1998). Further, our study provides a theoretical understanding of consumers' likely re-purchase intention. Consumers' repurchase intentions are based on, inter alia, their level of satisfaction with their service provider (Hellier, Geursen, Carr, \& Rickard, 2003), which has been empirically linked to brand loyalty (Lam, Ahearne, Hu, \& Schillewaert, 2010), via customer retention (Oyeniyi \& Joachim, 2008).

\section{Conclusion}

Market driven organizations are constantly trying to build and maintain brand loyalty amid strong competition. Nowhere is this more evident in the mobile telecommunications industry. The importance of loyalty stems from its positive consequences in relation to customer retention, repurchase, long-term customer relationships and profitability (Reichheld and Sasser, 1990). Central to this notion, is an understanding of what drives consumers' brand switching behavior, and what marketing strategies organizations can deploy to ensure long-term customer loyalty. The current study modeled brand switching behavior among mobile telecommunications consumers across four nations and provided evidence of the factors that are most likely to lead to brand switching behavior.

One limitation of the current study is that it examined brand switching behavior using six variables identified in the extant literature. Future work can examine latent variables that may influence brand switching behavior that are not considered in this study. By doing so, future studies can expand our understanding of brand switching behavior among consumers of mobile telephone services and suggest managerial decision associated with preventing such behavior.

Given the cross national nature of the current study, future scholarly work may address cultural (or sub-cultural) factors affecting brand switching behavior. Such a study would go beyond a nation's level of economic development (addressed in this study) to consider cultural dimensions that may affect brand switching. Indeed, cultural factors could have a moderating effect on consumers' tendencies to switch mobile telecommunications brands. 


\section{Acknowledgement}

This study is conducted by the Global Customer Experience team of The Nielsen Company as part of a global R\&D initiative. The authors wish to thank Dr. Nguyen Thi Binh, Statistical Consulting and Analysis team of The Nielsen Company, Vietnam.

\section{References}

Adjei, K., \& Denanyoh, R. (2014). Determinants of customer loyalty among mobile telecom subscribers in the Brong Ahafo Region of Ghana. International Journal of Business and Social Research, 4(1), 82-95.

Ahn, H., \& Lee, M.-H. (1999). An Econometric Analysis of the Demand for Access to Mobile Telephone Networks. Information Economics and Policy, 11(3), 297-305.

Ahn, J. H., Han, S. P., \& Lee, Y. S. (2006). Customer churn analysis: Churn determinants and mediation effects of partial defection in the Korean mobile telecommunications service industry. Telecommunications Policy, 30(10), 552-568.

Akroush, M. N., Abu-ElSamen, A. A., Al-Shibly, M. S., \& Al-Khawaldeh, F. M. (2010). Conceptualisation and development of customer service skills scale: an investigation of Jordanian customers. International Journal of Mobile Communications, 8(6), 625-653.

Al-Kwifi, O. S., \& Ahmed, Z. U. (2015). An intellectual journey into the historical evolution of marketing research in brand switching behavior-past, present and future. Journal of Management History, 21(2), 172-193.

Applbaum, K. (2000). Crossing borders: Globalization as myth and charter in American transnational consumer marketing. American Ethnologist, 27(2), 257-282.

Athanassopoulos, A. D. (2000). Customer satisfaction cues to support market segmentation and explain switching behavior. Journal of Business Research, 47(3), 191-207.

Bansal, H. S., \& Taylor, S. F. (1999). The service provider switching model (spsm) a model of consumer switching behavior in the services industry. Journal of Service Research, 2(2), 200-218.

Berry, M. J., \& Linoff, G. S. (2004). Data Mining Techniques for Marketing, Sales, and Customer Relationship Management. Indianapolis, USA: John Wiley \& Sons.

Burke, R. R. (2002). Technology and the customer interface: what consumers want in the physical and virtual store. Journal of the Academy of Marketing Science, 30(4), 411-432.

Burnham, T. A., Frels, J. K., \& Mahajan, V. (2003). Consumer switching costs: a typology, antecedents, and consequences. Journal of the Academy of Marketing Science, 31(2), 109-126.

Carraher, S. M., Carraher, S. C., \& Mintu-Wimsatt, A. (2005). Customer service management in Western and Central Europe: A concurrent validation strategy in entrepreneurial financial information services organizations. Journal of Business Strategies, 22(1), 41-54. 
Chae, M., Kim, J., Kim, H., \& Ryu, H. (2002). Information quality for mobile internet services: A theoretical model with empirical validation. Electronic Markets, 12(1), 38-46.

Chang, Y. H., \& Chen, F. Y. (2007). Relational benefits, switching barriers and loyalty: A study of airline customers in Taiwan. Journal of Air Transport Management, 13(2), 104-109.

Chin, W.W. (1998). Commentary: Issues and Opinion on Structural Equation Modeling. MIS Quarterly, 22(1), 6-16.

Chuang, Y. F. (2011). Pull-and-suck effects in Taiwan mobile phone subscribers switching intentions. Telecommunications Policy, 35(2), 128-140.

Coussement, K., Benoit, D. F., \& Van den Poel, D. (2010). Improved marketing decision making in a customer churn prediction context using generalized additive models. Expert Systems with Applications, 37(3), 2132-2143.

Dawar, N., \& Parker, P. (1994). Marketing universals: Consumers' use of brand name, price, physical appearance, and retailer reputation as signals of product quality. The Journal of Marketing, 81-95.

Dawes, J., \& Swailes, S. (1999). Retention sans frontieres: issues for financial service retailers. International Journal of Bank Marketing, 17(1), 36-43.

Dayton, C. M. (1992). Logistic Regression Analysis. Retrieved from http://84.89.132. 1/ satorra/dades/M2012LogisticRegressionDayton.pdf

De Ruyter, K., Wetzels, M., \& Bloemer, J. (1998). On the relationship between perceived service quality, service loyalty and switching costs. International Journal of Service Industry Management, 9(5), 436-453.

Duffy, J. (2000). Measuring customer capital. Strategy \& Leadership, 28(5), 10-15.

Eckhardt, G. M., \& Mahi, H. (2012). Globalization, consumer tensions, and the shaping of consumer culture in India. Journal of Macromarketing, 32(2), 280-294.

Edward, M., \& Sahadev, S. (2011). Role of switching costs in the service quality, perceived value, customer satisfaction and customer retention linkage. Asia Pacific Journal of Marketing and Logistics, 23(3), 327-345.

Farhat, R., \& Khan, B. M. (2011). Importance of brand personality to customer loyalty: A conceptual study. New Media and Mass Communication, 1(1), 4-10.

Feinberg, R. A., Kim, I. S., Hokama, L., de Ruyter, K., \& Keen, C. (2000). Operational determinants of caller satisfaction in the call center. International Journal of Service Industry Management, 11(2), 131-141.

Fornell, C., \& Wernerfelt, B. (1988). A model for customer complaint management. Marketing Science, 7(3), 287-298.

Gerpott, T. J., Rams, W., \& Schindler, A. (2001). Customer retention, loyalty, and satisfaction in the German mobile cellular telecommunications market. Telecommunications Policy, 25(4), 249-269.

Gerrard, P., \& Cunningham, J. B. (2004). Consumer switching behavior in the Asian banking market. Journal of Services Marketing, 18(3), 215-223.

Global Mobile Suppliers Association (2012). Retrieved from http://www.gsacom.com/.

Gremler, D. D., \& Brown, S. W. (1996). Service loyalty: its nature, importance, and implications. Advancing Service Quality: A Global Perspective. In B. Edvardsson, S. W. Brown, R. Johnston, and E. E. Scheuing (Eds.), Proceedings in American Marketing Association. QUIS V: Advancing Service Quality: A Global Perspective, ISQA, New York, NY, pp. 171-181.

Gruber, H. (2001). Competition and Innovation: The Diffusion of Mobile Telecommunications in Central and Eastern Europe. Information Economics and Policy, 13(1), 19-34. 
Gupta, R., \& Jain, K. (2012). Diffusion of mobile telecommunications in India: An empirical study. Technological Forecasting and Social Change, 79(4), 709-715.

Gupta, R., \& Jain, K. (2014). Adoption of mobile telecommunications in rural India: An empirical study. Decision Sciences, 45(2), 281-307.

Gupta, R., \& Jain, K. (2015). Adoption behavior of rural India for mobile telecommunications: A multi group study. Telecommunications Policy, 39(8), 691-704.

Gustafsson, A., Johnson, M. D., \& Roos, I. (2005). The effects of customer satisfaction, relationship commitment dimensions, and triggers on customer retention. Journal of Marketing, 69(4), 210-218.

Guzmán, F. (2012). Consumer Perception of Brand Equity Measurement: A New Scale (Doctoral dissertation). University of North Texas, USA.

Ha, H. Y., John, J., Janda, S. and Muthaly, S. (2011). The effects of advertising spending on brand loyalty in services. European Journal of Marketing, 45(4), 673-691.

Han, H., Back, K. J., \& Kim, Y. H. (2011). A multidimensional scale of switching barriers in the full-service restaurant industry. Cornell Hospitality Quarterly, 52(1), 54-63.

Harrison, T. (2000). Financial Services Marketing. London: Pearson Education Limited.

He, Y., Zou, D., \& Jin, L. (2010). Exploiting the goldmine: a lifestyle analysis of affluent Chinese consumers. Journal of Consumer Marketing, 27(7), 615-628.

Heide, J. B., \& Weiss, A. M. (1995). Vendor consideration and switching behavior for buyers in high-technology markets. The Journal of Marketing, 59(3), 30-43.

Hellier, P. K., Geursen, G. M., Carr, R. A., \& Rickard, J. A. (2003). Customer repurchase intention: A general structural equation model. European Journal of Marketing, 37(11/12), 1762-1800.

Heskett, J. L. (2002). Beyond customer loyalty. Managing Service Quality: An International Journal, 12(6), 355-357.

Hollebeek, L. D. (2011). Demystifying customer brand engagement: Exploring the loyalty nexus. Journal of Marketing Management, 27(7-8), 785-807.

Hossain, M. M., \& Suchy, N. J. (2013). Influence of customer satisfaction on loyalty: a study on mobile telecommunication industry. Journal of Social Sciences, 9(2), 73-80.

Hwang, J., Cho, Y., \& Long, N. V. (2009). Investigation of factors affecting the diffusion of mobile telephone services: An empirical analysis for Vietnam. Telecommunications Policy, 33(9), 534-543.

Iglesias, O., Singh, J. J., \& Batista-Foguet, J. M. (2011). The role of brand experience and affective commitment in determining brand loyalty. Journal of Brand Management, 18(8), 570-582.

ITU. (2002). World Development Report 2002 - Reinventing Telecoms. Geneva: International Telecommunication Union.

Jensen, S. (2006). Implementation of competitive nonlinear pricing: tariffs with inclusive consumption. Review of Economic Design, 10(1), 9-29.

Johnson, R. B., \& Onwuegbuzie, A. J. (2004). Mixed methods research: A research paradigm whose time has come. Educational Researcher, 33(7), 14-26.

Jones, M. A., Mothersbaugh, D. L., \& Beatty, S. E. (2000). Switching barriers and repurchase intentions in services. Journal of Retailing, 76(2), 259-274.

Kamboj, S., \& Rahman, Z. (2016). The influence of user participation in social mediabased brand communities on brand loyalty: age and gender as moderators. Journal of Brand Management, 23(6), 679-700. 
Kaur, G., \& Sambyal, R. (2016). Exploring Predictive Switching Factors for Mobile Number Portability. Vikalpa, The Journal for Decision Makers , 41(1), 74-95.

Keaveney, S. M. (1995). Customer switching behavior in service industries: An exploratory study. The Journal of Marketing, 59(2), 71-82.

Keaveney, S. M., \& Parthasarathy, M. (2001). Customer switching behavior in online services: An exploratory study of the role of selected attitudinal, behavioral, and demographic factors. Journal of the Academy of Marketing Science, 29(4), 374390.

Kim, M. K., Park, M. C., \& Jeong, D. H. (2004). The effects of customer satisfaction and switching barrier on customer loyalty in Korean mobile telecommunication services. Telecommunications Policy, 28(2), 145-159.

Kim, H. S., \& Yoon, C. H. (2004). Determinants of subscriber churn and customer loyalty in the Korean mobile telecommunications market. Telecommunications Policy, 28(9), 751-765.

Kouser, R., Qureshi, S., Shahzad, F. A., \& Hasan, H. (2012). Factors influencing the customer's satisfaction and switching behavior in cellular services of Pakistan. Interdisciplinary Journal of Research in Business, 2(1), 15-25.

Lai, F., Griffin, M., \& Babin, B. J. (2009). How quality, value, image, and satisfaction create loyalty at a Chinese telecom. Journal of Business Research, 62(10), 980-986.

Lam, S. K., Ahearne, M., Hu, Y., \& Schillewaert, N. (2010). Resistance to brand switching when a radically new brand is introduced: A social identity theory perspective. Journal of Marketing, 74(6), 128-146.

Li, D., Jiang, Y., An, S., Shen, Z., \& Jin, W. (2009). The influence of money attitudes on young Chinese consumers' compulsive buying. young consumers, 10(2), 98-109.

Lee, M., \& Cunningham, L. F. (2001). A cost/benefit approach to understanding service loyalty. Journal of Services Marketing, 15(2), 113-130.

Lee, R., \& Neale, L. (2012). Interactions and consequences of inertia and switching costs. Journal of Services Marketing, 26 (5), 365-374.

Lee, J., Lee, J., \& Feick, L. (2001). The impact of switching costs on the customer satisfaction-loyalty link: mobile phone service in France. Journal of Services Marketing, 15(1), 35-48.

Lim, H., Widdows, R., \& Park, J. (2006). M-loyalty: winning strategies for mobile carriers. Journal of Consumer Marketing, 23(4), 208-218.

Liu, X., Wu, F. S., \& Chu, W. L. (2009). Innovation diffusion: mobile telecommunications adoption in China. International Journal of Innovation Management, 13(2), 245-271.

Madden, G., Coble-Neal, G., \& Dalzell, B. (2004). A dynamic model of mobile telecommunications subscription incorporating a network effect. Telecommunications Policy, 28(2): 133-144.

Madden, G., Savage, S. J., \& Coble-Neal, G. (1999). Subscriber churn in the Australian ISP market. Information Economics and Policy, 11(2), 195-207.

Malhotra, A., \& Kubowicz Malhotra, C. (2013). Exploring switching behavior of US mobile service customers. Journal of Services Marketing, 27(1), 13-24.

Manrai, L. A., \& Manrai, A. K. (2007). A field study of customers' switching behavior for bank services. Journal of Retailing and Consumer Services, 14(3), 208-215.

Marsico, K. (1996). Call centers: today's new profit centers, AT\&T Technology, 10(4), 14-18.

Martins, R. C., Hor-Meyll, L. F., \& Ferreira, J. B. (2013). Factors affecting mobile users' switching intentions: A comparative study between the Brazilian and German markets. BAR-Brazilian Administration Review, 10(3), 239-262.

Money, R. B. (2004). Promotion and switching behavior in Japanese and American business-to-business service clients. Journal of Business Research, 57, 297-305. 
Ngai, E. W. T. (2005). Customer relationship management research (1992-2002): An academic literature review and classification. Marketing Intelligence \& Planning, 23(6), 582-605.

Nimako, S. G., Ntim, B. A., \& Mensah, A. F. (2014). Effect of Mobile Number Portability Adoption on Consumer Switching Intention. International Journal of Marketing Studies, 6(2), 117-134.

Noorderhaven, N. G., \& Harzing, A. W. (2003). The "country-of-origin effect" in multinational corporations: Sources, mechanisms and moderating conditions. Management and International Review, 47-66.

Nguyen, T. H., Sherif, J. S., \& Newby, M. (2007). Strategies for successful CRM implementation. Information Management \& Computer Security, 15(2), 102-115.

Ooko, D., Nzomoi, J., \& Mumo, R. (2014). Determinants of consumer switching behavior in mobile telecommunications industry in Kenya. International Journal of Business and Commerce, 3(5), 82-98.

Oyeniyi, O., \& Joachim, A. A. (2008). Customer service in the retention of mobile phone users in Nigeria. African Journal of Business Management, 2(2), 26-34.

Ping Jnr, R.A. (1994). Does satisfaction moderate the association between alternative attractiveness and exit intention in a marketing channel? Journal of the Academy of Marketing Science, 22(4), 364-371.

Ramaseshan, B., \& Stein, A. (2014). Connecting the dots between brand experience and brand loyalty: The mediating role of brand personality and brand relationships. Journal of Brand Management, 21(7-8), 664-683.

Ranganathan, C., Seo, D., \& Babad, Y. (2006). Switching behavior of mobile users: do users' relational investments and demographics matter?. European Journal of Information Systems, 15(3), 269-276.

Reichheld, F. P., \& Sasser, W. E. (1990). Zero defections: Quality Comes to Services. Harvard Business Review, 68(5), 105-111.

Reisinger, H. (1997). The Impact of Research Designs on $\mathrm{R}^{2}$ in Linear Regression Models: An Exploratory Meta-Analysis. Journal of Empirical Generalizations in Marketing Science, 2, 1-12.

Rogers, E. (1995). The Diffusion of Innovations. (4th ed.). New York, NY: The Free Press.

Roto, V., Geisler, R., Kaikkonen, A., Popescu, A., \& Vartiainen, E. (2006, May). Data traffic costs and mobile browsing user experience. Proceedings of the 4th MobEA Workshop on Empowering the Mobile Web, pp. 1-6.

Rouvinen, P. (2006). Diffusion of digital mobile telecommunications: Are developing countries different? Telecommunications Policy, 30(1), 46-63.

Roy, P., Khandeparkar, K., \& Motiani, M. (2016). A lovable personality: The effect of brand personality on brand love. Journal of Brand Management, 23(5), 97-113.

Santouridis, I., \& Trivellas, P. (2010). Investigating the impact of service quality and customer satisfaction on customer loyalty in mobile telecommunications in Greece. The TQM Journal, 22(3), 330-343.

Sekaran, U. (1983). Methodological and theoretical issues and advancements in crosscultural research. Journal of International Business Studies, 14(2), 61-73.

Seo, D., Ranganathan, C., \& Babad, Y. (2008). Two-level model of customer retention in the US mobile telecommunications service market. Telecommunications Policy, 32(3), 182-196.

Shin, D. H., \& Kim, W. Y. (2008). Forecasting customer switching intention in mobile service: An exploratory study of predictive factors in mobile number portability. Technological Forecasting and Social Change, 75(6), 854-874. 
Sin, L. Y., Cheung, G. W., \& Lee, R. (1999). Methodology in cross-cultural consumer research: A review and critical assessment. Journal of International Consumer Marketing, 11(4), 75-96.

Smith, D. E., \& Mitry, D. J. (2007). Cultural convergence: consumer behavioral changes in the European wine market. Journal of Wine Research, 18(2), 107-112.

Svendsen, G. B., \& Prebensen, N. K. (2013). The effect of brand on churn in the telecommunications sector. European Journal of Marketing, 47(8), 1177-1189.

Van Doorn, J., Lemon, K. N., Mittal, V., Nass, S., Pick, D., Pirner, P., \& Verhoef, P. C. (2010). Customer engagement behavior: Theoretical foundations and research directions. Journal of Service Research, 13(3), 253-266.

Vázquez-Carrasco, R., \& Foxall, G. R. (2006). Positive vs. negative switching barriers: The influence of service consumers' need for variety. Journal of Consumer Behaviour, 5(4), 367-379.

Verhoef, P. C. (2003). Understanding the effect of customer relationship management efforts on customer retention and customer share development. Journal of Marketing, 67(4), 30-45.

Verhoef, P. C., Lemon, K. N., Parasuraman, A., Roggeveen, A., Tsiros, M., \& Schlesinger, L. A. (2009). Customer experience creation: Determinants, dynamics and management strategies. Journal of Retailing, 85(1), 31-41.

Worthington, S., Russell-Bennett, R., \& Härtel, C. (2010). A tri-dimensional approach for auditing brand loyalty. Journal of Brand Management, 17(4), 243-253.

Yun, X. (2012). Chinese use of mobile texting for social interactions: Cultural implications in the use of communication technology. Intercultural Communication Studies, 21(2), 131-150.

Zeithaml, V. A., Berry, L. L., \& Parasuraman, A. (1996). The behavioral consequences of service quality. The Journal of Marketing, 60(2), 31-46.

Zheng, Y. (1994). Development and democracy: are they compatible in China? Political Science Quarterly, 109(2), 235-259. 